\title{
Antibacterial Activity of Leaves Extract of Bukkol (Ziziphus mauritania Lam) against E.coli and S.aureus
}

\section{Laila Khamsatul Muharrami ${ }^{1}$, Fatimatul Munawaroh ${ }^{1}$, Taslim Ersam², Mardi Santoso ${ }^{2}$, Eko Setiawan ${ }^{3}$, Yunin Hidayati ${ }^{1}$, and Irsad Rosidi ${ }^{1}$}

${ }^{1}$ Natural Science Education Study Program,Faculty of Education, University of Trunojoyo Madura, Bangkalan, Indonesia

${ }^{2}$ Chemistry Departemen, Faculty of Natural Science, Sepuluh Nopember Institute of Technology, Surabaya, Indonesia

${ }^{3}$ Agroecotechnology Study Program,Faculty of Agriculture, University of Trunojoyo Madura, Bangkalan, Indonesia

\section{Abstract}

Bukkol (Ziziphus mauritania Lam) has potential as bioactive compounds. The present research aims to investigate the phytochemical screening and antibacterial activity of

Corresponding Author: Laila Khamsatul Muharrami laila@trunojoyo.ac.id

Received: 19 February 2019 Accepted: 5 March 2019 Published: 16 April 2019

Publishing services provided by Knowledge E

(c) Laila Khamsatul Muharrami et al. This article is distributed under the terms of the

Commons Attribution License, which permits unrestricted use and redistribution provided that the original author and source are credited.

Selection and Peer-review unde the responsibility of the ICBSA Conference Committee.

\section{G OPEN ACCESS} the crude ethanolic extract of Ziziphus mauritania Lam against E. coli and S.aureus. The concentration of ethanolic extract of Ziziphus mauritania Lam leaves were $1 \%, 10 \%$, $20 \%, 30 \%$, and $40 \%$. The method analyzed by the paper disc method (agar plate). The result of phytochemical screening shown that extract of Ziziphus mauritania Lam leaves has the detectable amount of secondary metabolites like flavonoids, tannins, saponins, and steroids. The result of ethanolic extract of Ziziphus mauritiana Lam leaves against S.aureus with the concentration of $1 \%, 10 \%, 20 \%, 30 \%$ and $40 \%$ indicating antibacterial activity which are $0 \mathrm{~mm} ; 0,92 \pm 0,056 \mathrm{~mm} ; 1,22 \pm 0,021 \mathrm{~mm} ; 1,36 \pm 0,017 \mathrm{~mm}$ and $1,68 \pm 0,03 \mathrm{~mm}$. While extract of Ziziphus mauritania Lam leaves has no antibacterial activity against E.coli growth.

Keywords: Ziziphus mauritiana Lam, phytochemical screening, antibacterial activity

\section{Introduction}

The potency of medicinal plants in Indonesia is very abundant, especially on Madura Island [1]. The medicinal plants have great importance for human beings. The medicinal plants have chemical constituents called secondary metabolites [2]. Bukkol (Ziziphus mauritiana) is one of a medicinal plant from genus Ziziphus belongs to Rhamnaceae family [3, 4]. Furthermore, Z.mauritiana could found in the environment around. Distribution of this genus in the tropical and subtropical regions of the world [3, 4]. Z.mauritiana is used to various nutrition and traditional medicine for human ailments [4-6]. The fruit contains relatively high vitamin C. It contains $20-30 \%$ sugar, more protein from $2.5 \%$ and 
12.8\% carbohydrates [7]. The leaves, on generally used for treat diarrhea, stop nausea, vomiting, asthma, fever and anti dermatitis [3-5,8]. Besides, some research shows that metabolites secondary on Z. mauritania leaves contain flavonoids, alkaloids, tannins, and phenolic compounds $[2-5,8,9]$.

It shows that $Z$. mauritiana has potency as antibacterial. Antibiotics are systematic from organic ingredients for inhibitor destroy bacteria certain [10]. However, conditions that in low levels [10]. The biggest problem in the drug industry that is resistance bacteria against Z.mauritiana [2]. Content metabolites secondary, one of them, tannin has activity biological as an antibiotic [1]. Then, ethanol on Z. Mauritiana Leaves also effective for answer bacteria good gram-positive or negative [9].

Therefore, the need for information more goes on related womb metabolite secondary on Z. mauritiana can be used as antibacterial [11]. On this research, Z. mauritiana was taken from wild plants (not plant cultivation) located on the island.

\section{Materials and Methods}

\subsection{Plant material}

Leaves of Bukkol (Ziziphus Mauritania) (wild type) collected from the surroundings of Gili Timur district, Kamal, Bangkalan, Madura. The specimen has deposited at Department of Natural Science Education. Samples were crushed and put into a glass container and saved until the extraction procedure performed in the laboratory.

\subsection{Chemicals}

Ethanol 96\%, aquadest, chloroform, acetone pa, sulfuric acid, MHA media, $\mathrm{NaCl}$, sterile stick cotton, Whatman filter paper, E. coli, S. aureus and reagents for phytochemical tests.

\subsection{Preparation of extracts}

Leaves of samples were adequately dried and smoothed into a grainy powder. Each of $50 \mathrm{~g}$ grinded powders was soaked into 500 ethanol 96\%, separated for three days. After three days of dissolving, then the mixture was filtered. Then, filtrates were evaporated using rotary evaporator. 


\subsection{Bacterial suspension}

E.coli and S.aureus colonies ( 24 hours) were taken with oasis wire and then suspended into sterile aquadest by applying bacterial colonies to the test tube wall and then stirred with distilled water to form turbidity or density.

\subsection{Antibacterial activity}

The antibacterial activity used Kirby Bauer method (using a disc). The media used $19 \mathrm{~g}$ of Mueller-Hinton Agar (MHA) was dissolved in $0.5 \mathrm{~L}$ distilled water, and then sterilized in an autoclave at $121^{\circ} \mathrm{C}$ for 15 minutes. Each petri dish was filled with $15-20 \mathrm{~mL}$ of MHA media and left for a while until it solidified. In solid media $0.1 \mathrm{~mL}$, the bacterial suspension was distributed which was adjusted to the standard using spreader rods. The first media MHA was divided into 7 parts, each of which was placed in a disc containing ethanol extract of plant leaves $Z$. mauritania with a concentration of control positive (tetracycline), control negative (DMSO), ethanolic extract of $Z$. mauritiana with $1 \%, 10 \%, 20 \%, 30 \%$ and $40 \%$. Then incubated at $37^{\circ} \mathrm{C}$ for 24 hours and observed bacterial growth at each concentration. The length of the inhibitory zone formed is measured by a ruler in millimeters.

\section{Result and Discussion}

\subsection{Preliminary phytochemical screening}

Phytochemical screening results of ethanolic extract of Z. mauritiana leaves showed that the extracts of $Z$. mauritiana contained secondary metabolites (Table 1). Phytochemical screening is used to identify secondary metabolites like alkaloids, phenolic compounds, flavonoids, steroids, etc. [12].

TABLE 1: Phytochemical constituents of ethanolic extract of Z. mauritiana.

Chemicals Constituents
Alkaloids
Saponins
Flavonoids
Tannins
Terpenoids
Steroids

Ethanol extract
-
+
+
+
-
+


In this research, the results of preliminary phytochemical screening for the ethanolic extract of $Z$. mauritiana leaves confirmed the presence of secondary metabolites like tannins, steroids, saponins, and flavonoids (Table 1). The result of this research was also supported by previous research as shown in Ref [9], leaves of Z.mauritiana contain phenolic compounds, saponins, and tannins; Parmar P. et al. showed that leaves of Z.mauritiana possess saponins, phenolic compounds, lignins, tannins, and glycosides [13]; Abdallah E.M et al. showed that extract of $Z$. mauritiana leaves possess terpenoids, saponins [4], alkaloids, tannins, and phenolic compounds. Phytochemical screening of $Z$. mauritiana leaves extract rich in various bioactive constituents like flavonoids, saponins, resins, tannins, coumarins, cardiac glycosides, phenols, phytosterols, quinones and terpenoids [2].

Based from Table 1, the result of phytochemical screening were not found alkaloids and terpenoids compound. This is supported by Afnidar as shown in Ref [14] that each plant has an almost limited ability to synthesize secondary metabolite. The secondary metabolite have an ability to against microorganisms and insects; the secondary metabolites are molecules have specific properties (not all organisms contain similar compounds), have various structures, each compound has a different function [14].

\subsection{Antibacterial activity}

Z.mauritiana leaves extract in Islam are recommended according to the Sunnah, (extract in water) is used for a person who embraces Islam to bathe with Z. mauritiana extract [15]. Bioactivity of the plant caused by these plant contains secondary metabolite compounds [15]. As explained in previous studies about the phytochemistry content of Z.mauritiana extract which acts as traditional medicine, among others extracts from water obtained tannins and saponins, while extracts from alcohol obtained flavonoids, glycosides, alkaloids, and phenols which act as antibacterial [9]; flavonoids, alkaloids, glycoside, steroids, phenols, tannins, saponins, sterols and terpenoids which act as antioxidants and antibacterial; tannins, terpenoids, and flavonoids as antimicrobials [16]. This shows that there is a belief in Z.mauritiana can provide an antibacterial effect. The result of the antibacterial activity of the ethanolic extract from $Z$. mauritiana leaves who taken from the wild plant that grows in Gili Timur, Bangkalan, East Java-Indonesia are shown in Table 2.

Based on Table 2 and Fig.1(b), the inhibition zone on E. coli growth at one-week observation showed that at concentrations of $1 \%, 10 \%, 20 \%, 30 \%$ and $40 \%$ with three repetitions showed no antibacterial activity against $E$. coli growth. This can be seen by 
TABLE 2: Antibacterial activity of the ethanolic extract of $Z$. mauritiana Leaves.

No.
1
1
2
3
4
5
6
7

\begin{tabular}{c}
$\begin{array}{c}\text { Extract Concentration } \\
(\%)\end{array}$ \\
\hline 1 \\
10 \\
20 \\
30 \\
40 \\
\hline Control (+) \\
\hline Control (-)
\end{tabular}

\begin{tabular}{|c|c|}
\hline \multicolumn{2}{|c|}{ Diameter of Inhibition Zone $(\mathbf{m m})$} \\
\hline S. aureus & E. coli \\
\hline 0 & 0 \\
\hline $0,92 \pm 0,056$ & 0 \\
\hline $1,22 \pm 0,021$ & 0 \\
\hline $1,36 \pm 0,017$ & 0 \\
\hline $1,68 \pm 0,03$ & 0 \\
\hline $3,73 \pm 0,522$ & $2,92 \pm 0,313$ \\
\hline 0 & 0 \\
\hline
\end{tabular}

the formation of an inhibitory zone around the disc. No inhibition zone formation due to the resulting ethanol extract of $Z$. mauritiana leaves was a crude extract [14]. This is reinforced by the research of [17] which showed that low concentrations of $Z$. mauritiana extract have not been able to damage the cell wall of $E$. coli bacteria. This does not mean that the sample is not active, but is likely to be influenced by the concentration of the test sample used. Positive control of tetracycline solution shows the inhibition zone formed around the disc with an average inhibition zone diameter of $2.92 \pm 0.313$ $\mathrm{mm}$. Negative control of DMSO solution shows that there is no antibacterial activity characterized by no formation of inhibitory zones around the disc.

While based Table 2 and Fig.1 (a) the inhibitory test results of ethanol extract of $Z$. mauritiana leaves on growth of $S$. aureus for 1 week were obtained at concentrations of $1 \%, 10 \%, 20 \%, 30 \%$ and $40 \%$ with three repetitions indicating antibacterial activity which are 0,92 $\pm 0,056 \mathrm{~mm} ; 1,22 \pm 0,021 \mathrm{~mm} ; 1,36 \pm 0,017 \mathrm{~mm}$ and 1,68 $\pm 0,03 \mathrm{~mm}$. The difference in antibacterial activity at each concentration depends on the concentration, chemical structure and species of the bacteria [18]. The presence of antibacterial activity is indicated by the inhibition zone around the disc. This antibacterial activity is caused by the presence of secondary metabolites in Z. mauritiana leaves such as tannins, steroids, saponins, and flavonoids (Table 1).

Crude extracts of plants often used as traditional medicine have been investigated for antibacterial activity; several previous studies have supported this, including; Fiori et al. was found that tannins tested exhibited various antibacterial and anti-yeast activities [19]; Akiyama et al. (2001) tannin have shown potency as antibacterial [20]; Sung Si Heung (2012) the tannin extract of distilled water from chestnut hull have shown maximum antibacterial activity against S. flexneri, followed by B. coagulants [21]; Tannins are polyphenolic compounds used as chemical defenses against herbivory and pathogens [22] (Gedir et al., 2005). There are having antimicrobial activity [23]. "Wafa Nouioua 


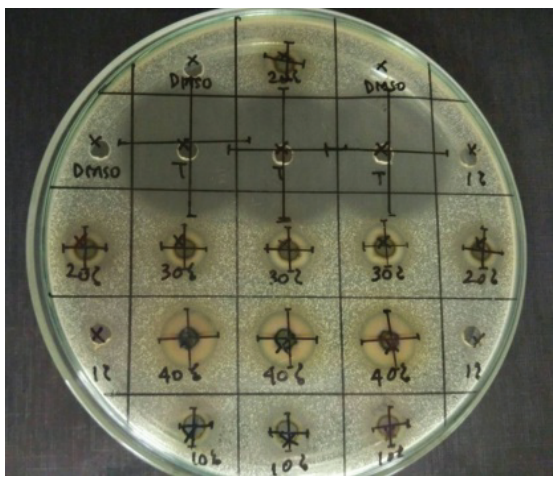

(a)

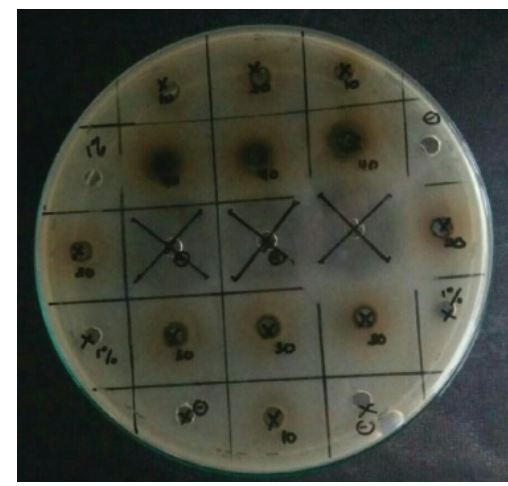

(b)

Figure 1: Inhibition zone of extract Z. mauritiana leaves: (a). S. aureus and (b) E. coli.

[24]" showed that tannins and flavonoids extracted from Phlomisbovei De Noé, present potential as antimicrobial and antioxidant activities [24]. Flavonoids in some plants are known to have antibacterial properties [25]. "Manik et al. [26]" said that the total flavonoid content affect the magnitude of antibacterial activity. "Cushnie et al. [27] identified the structures of flavonoids possessing antiviral antifungal and antibacterial activity.

Related studies of antibacterial activity show that crude extracts containing triterpenes, flavonoids, and steroids have significant activity against various strains of Staphylococcus aureus, Escherichia coli and Streptococcus faecalis [28]. The chemical structural properties of the steroid-antibiotic agents which seem to be the key needed to antibacterial activity. It has also been suggested that membrane selectivity is primarily derived from the ionic recognition of negatively charged bacterial membranes. Also, several studies suggest that functional groups of steroid derivative are involved in the bacterial activity [29].

The mechanism of saponins as an antibacterial is to reduce surface tension resulting in increased permeability or damage of cells and resulting intracellular compounds will exit [30]. According to Ref [31], this compound diffuses through the outer membrane and cell walls, then binds to the cytoplasmic membrane and reduces the stability. This causes the cytoplasm to leak out of the cell which results in cell death [32]. Saponins work as antimicrobials because saponin compounds can perform inhibitory mechanisms by forming complex compounds with cell membranes through hydrogen bonds, to destroy the permeability properties of bacterial cell walls and cause bacterial cell death [33].

According to Ref [34], the inhibitory zone shows the sensitivity of bacteria to antibacterial activity. This is supported by [35]that the ability of antibacterial substances to inhibit bacterial growth can be determined by measuring the inhibitory zones formed around the disc. However, at a concentration of $1 \%$ does not show antibacterial activity against 
E.coli growth. Positive control of tetracycline solution shows the inhibition zone formed around the disc with an average inhibition zone diameter of $3.73 \pm 0.522 \mathrm{~mm}$. Negative control of DMSO solution shows that there is no antibacterial activity characterized by no formation of inhibitory zones around the disc.

\section{Conclusions}

The crude ethanolic extract of $Z$. mauritiana leaves has phytochemical constituents including tannins, saponins, steroids, and flavonoids. The ethanolic extract of Z.mauritiana leaves against S.aureus with optimal concentration in $40 \%$ that indicating antibacterial activity which is $1,68 \pm 0,03 \mathrm{~mm}$. While extract of Z.mauritania leaves has no antibacterial activity against E.coli growth.

\section{Acknowledgments}

This paper is part of research funded by Directorate General of Research and Development Affirmation, Ministry of Research, Technology, and Higher Education of the Republic of Indonesia. For this, the authors convey many thanks for the financial supports. We would like to thank LPPM of Trunojoyo Madura University, students of Natural Science Education, and those who support this research's smoothness and success as well.

\section{References}

[1] M. Maharrami, L.K., Munawaroh, F., Ersam, T. dan Santoso, "Inventarisasi Tumbuhan Jamu dan Skrining Fitokimia Kabupaten Sampang," J. Pena Sains, vol. 4, no. 2, 2017.

[2] A. Al Ghasham et al., "Phytochemical Screening, Antioxidant and Antimicrobial Activities of Methanolic Extract of Ziziphus mauritiana Lam. Leaves Collected from Unaizah, Saudi Arabia," Int. J. Pharm. Res. Allied Sci., vol. 6, no. 3, pp. 33-46, 2017.

[3] A. M. Bukar, M. Z. Kyari, P. A. Gwaski, M. Gudusu, F. S. Kuburi, and Y. I. Abadam, "Evaluation of phytochemical and potential antibacterial activity of Ziziphus spinachristi L. against some medically important pathogenic bacteria obtained from University of Maiduguri Teaching Hospital, Maiduguri, Borno State - Nigeria," J. Pharmacogn. Phytochem. JPP, vol. 3, no. 35, pp. 98-101, 2015.

[4] E. M. Abdallah, E. R. Elsharkawy, and A. Ed-Dra, "Biological activities of methanolic leaf extract of Ziziphus mauritiana," Pharm. Commun. Biosci. Biotech. Res. Comm. 
Thomson Reuters ISI ESC Crossref Index. J. NAAS J. Score, vol. 9, no. 4, pp. 605-614, 2016.

[5] I. Ipandi, L. Triyasmono, and B. Prayitno, "Penentuan Kadar Flavonoid Total dan Aktivitas Antioksidan Ekstrak Etanol Daun Kajajahi (Leucosyke capitellata Wedd.)," Pharmascience, vol. 3, no. 1, pp. 93-100, 2016.

[6] E. N. Ads, S. Rajendrasozhan, S. I. Hassan, S. M. Sayed, and J. R. Humaidi, "Phytochemical, antimicrobial and cytotoxic evaluation of Ziziphus spina- christi (L.) stem bark.," vol. 28, no. 15, pp. 6646-6653, 2017.

[7] C. Priyanka, P. Kumar, S. P. Bankar, and L. Karthik, "In vitro antibacterial activity and gas chromatography-mass spectroscopy analysis of Acacia karoo and Ziziphus mauritiana extracts," J. Taibah Univ. Sci., vol. 9, no. 1, pp. 13-19, 2015.

[8] M. E. Abalaka, S. Y. Daniyan, and A. Mann, "Evaluation of the antimicrobial activities of two Ziziphus species (Ziziphus mauritiana L. and Ziziphus spinachristi L.) on some microbial pathogens," African J. Pharm. Pharmacol. Vol., vol. 4, no. 4, pp. 135-139, 2010.

[9] S. Najafi, "Phytochemical Screening And Antibacterial Activity Of Leaf Extract Of Ziziphus Mauritiana Lam," Int. Res. J. Appl. Basic Sci., vol. 2, no. 3, pp. 3274-3276, 2013.

[10] V. Nagumanthri, S. Rahiman, B. Ahmad Tantry, P. Nissankararao, and M. Phani kumar, "In vitro antimicrobial activity of Acacia nilotica, Ziziphus mauritiana, Bauhinia variegate and Lantana camara against some clinical isolated strains," Iran. J. Sci. Technol. Trans. A Sci., vol. 36, no. 2, pp. 213-217, 2012.

[11] N. S. Sameera and B. P. Mandakini, "Investigations into the antibacterial activity of Ziziphus mauritiana Lam. and Ziziphus xylopyra (Retz.) Willd.," Int. Food Res. J., vol. 22, no. 2, pp. 849-853, 2015.

[12] A.; R. M. L.; and N. S. Sasikala, "Quantification of Primary and Secondary Metabolites From Leaves and Stem Bark of Cochlospermum Religiosum (L) Alston," Int. Res. J. Pharm., vol. 4, no. 8, pp. 228-231, 2013.

[13] P. Parmar, S. Bhatt, S. Dhyani, and A. Jain, "Phytochemical Studies of the Secondary Metabolites of Ziziphus Mauritiana," Int. J., vol. 4, no. 3, pp. 3-5, 2012.

[14] Afnidar, "Fitokimia Dan Uji Aktivitas Antibakteri Ekstrak Kalus Tumbuhan Sernai (Wedelia biflora (L) DC.)," Jesbio, vol. III, no. 4, pp. 9-16, 2014.

[15] A. P. Asmara, "Uji Fitokimia Senyawa Metabolit Sekunder Dalam Ekstrak Metanol Bunga Turi Merah (Sesbania grandiflora L. Pers)," Al-Kimia, vol. 5, no. 1, pp. 48-59, 2017. 
[16] M. MA, M. AM, U. IA, A. DA, I. Joseph, and P. Amos, "Phytochemical Screening and Antimicrobial Activity of the Pulp Extract and Fractions of Ziziphus mauritiana," Biochem. Anal. Biochem., vol. 07, no. 02, 2017.

[17] M. S. Saroinsong, F. E. F. Kandou, A. Papu, and M. F. O. Singkoh, “Uji Daya Hambat Ekstrak Metanol Beberapa Jenis Porifera Terhadap Bakteri Escherichia coli dan Staphylococcus aureus," vol. 3, no. 2, pp. 129-133, 2014.

[18] Adawiah, D. Sukandar, and A. Muawanah, "'Aktivitas Antioksidan dan Kandungan Komponen Bioaktif Sari Buah Namnam,"' J. Kim. Val. J. Penelit. dan Pengemb. IImi Kim., vol. 1, no. 2, pp. 130-136, 2015.

[19] G. M. Lanchoti Fiori et al., "Antimicrobial Activity and Rates of Tannins in Stryphnodendron adstringens; Mart. Accessions Collected in the Brazilian Cerrado," Am. J. Plant Sci., vol. 04, no. 11, pp. 2193-2198, 2013.

[20] H. Akiyama, "Antibacterial action of several tannins against Staphylococcus aureus," J. Antimicrob. Chemother., vol. 48, no. 4, pp. 487-491, 2001.

[21] Si Heung Sung, "Antibacterial and antioxidant activities of tannins extracted from agricultural by-products," J. Med. Plants Res., vol. 6, no. 15, pp. 3072-3079, 2012.

[22] J. V. Gedir, P. Sporns, and R. J. Hudson, "Extraction of condensed tannins from cervid feed and feces and quantification using a radial diffusion assay," J. Chem. Ecol., vol. 31, no. 12, pp. 2761-2773, 2005.

[23] Doughari, "Antimicrobial activity of leaf extracts of Senna obtusifolia (L)," African J. Pharm. Pharmacol., vol. 2, no. 1, pp. 7-13, 2008.

[24] N. Wafa, G. Sofiane, and K. Mouhamed, "The antioxidant and antimicrobial activities of flavonoids and tannins extracted from Phlomis bovei De Noé," Eur. J. Exp. Biol., vol. 6, no. 3, pp. 55-61, 2016.

[25] O. K. Mirzoeva, R. N. Grishanin, and P. C. Calder, "Antimicrobial action of propolis and some of its components: The effects on growth, membrane potential and motility of bacteria," Microbiol. Res., vol. 152, no. 3, pp. 239-246, 1997.

[26] D. F. Manik and T. Hertiani, "Dengan Aktivitas Antibakteri Ekstrak Etanol Dan FraksiFraksi Daun Kersen," pp. 1-11.

[27] T. P. T. Cushnie and A. J. Lamb, “Antimicrobial activity of flavonoids," Int. J. Antimicrob. Agents, vol. 26, no. 5, pp. 343-356, 2005.

[28] D. Chattopadhyay et al., "Antimicrobial activity of Alstonia macrophylla: A folklore of bay islands," J. Ethnopharmacol., vol. 77, no. 1, pp. 49-55, 2001.

[29] L. Figueroa-Valvere, F. Díaz-Cedillo, M. Lopez-Ramos, E. Garcia-Cervera, E. Pool Gomez, and R. Torres-Cutz, "Antibacterial activity induced by several steroid 
derivatives against E. coli,S. Typhi, K. pneumoniae and S. aureus," Bio Technol., vol. 40, pp. 5452-5455, 2011.

[30] M. Nuria, A. Faizatun, and Sumantri, “Uji aktivitas antibakteri ekstrak etanol daun jarak pagar (Jattopha curcas L) terhadap bakteri Staphylococcus aureus ATCC 25923, Escherichia coli ATCC 25922, dan Salmonella typhi ATCC 1408," Mediagro, vol. 26, no. 2, pp. 26-37, 2009.

[31] American Society for Microbiology, Manual of antimicrobial susceptibility testing. 2005.

[32] M. Ngajow, J. Abidjulu, and V. S. Kamu, "Pengaruh Antibakteri Ekstrak Kulit Batang Matoa (Pometia pinnata) terhadap Bakteri Staphylococcus aureus secara In vitro," J. MIPA UNSRAT, vol. 2, no. November 2013, pp. 128-132, 2013.

[33] Ernawati and K. Sari, "Kandungan Senyawa Kimia Dan Aktivitas Antibakteri Ekstrak Kulit Buah Alpukat (Persea Americana P.Mill) Terhadap Bakteri Vibrio Alginolyticus," vol. V, no. 2, pp. 203-211, 2015.

[34] S. Sumarsih, Diktat Kuliah Mikrobiologi Dasar. Yogyakarta: Jurusan IImu Tanah Fakultas Pertanian UPN Veteran Yogyakarta, 2003.

[35] G. F. Brooks, K. C. Carroll, J. Butel, S. A. Morse, and T. Mietzner, Medical Microbiology. 2013. 